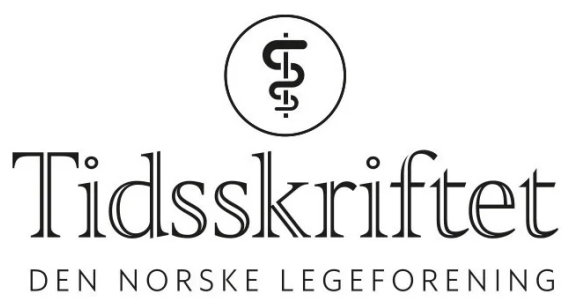

\title{
Covid-19: Slå ring!
}

REDAKSJONELL KOMMENTAR

\section{KARI TVEITO}

kari.tveito@tidsskriftet.no

Kari Tveito er lege, ph.d. og medisinsk redaktør i Tidsskriftet.

Forfatteren har fylt ut ICMJE-skjemaet og oppgir ingen interessekonflikter.

\section{Sangen fra Italia har nådd Norge.}

Foto: Einar Nilsen

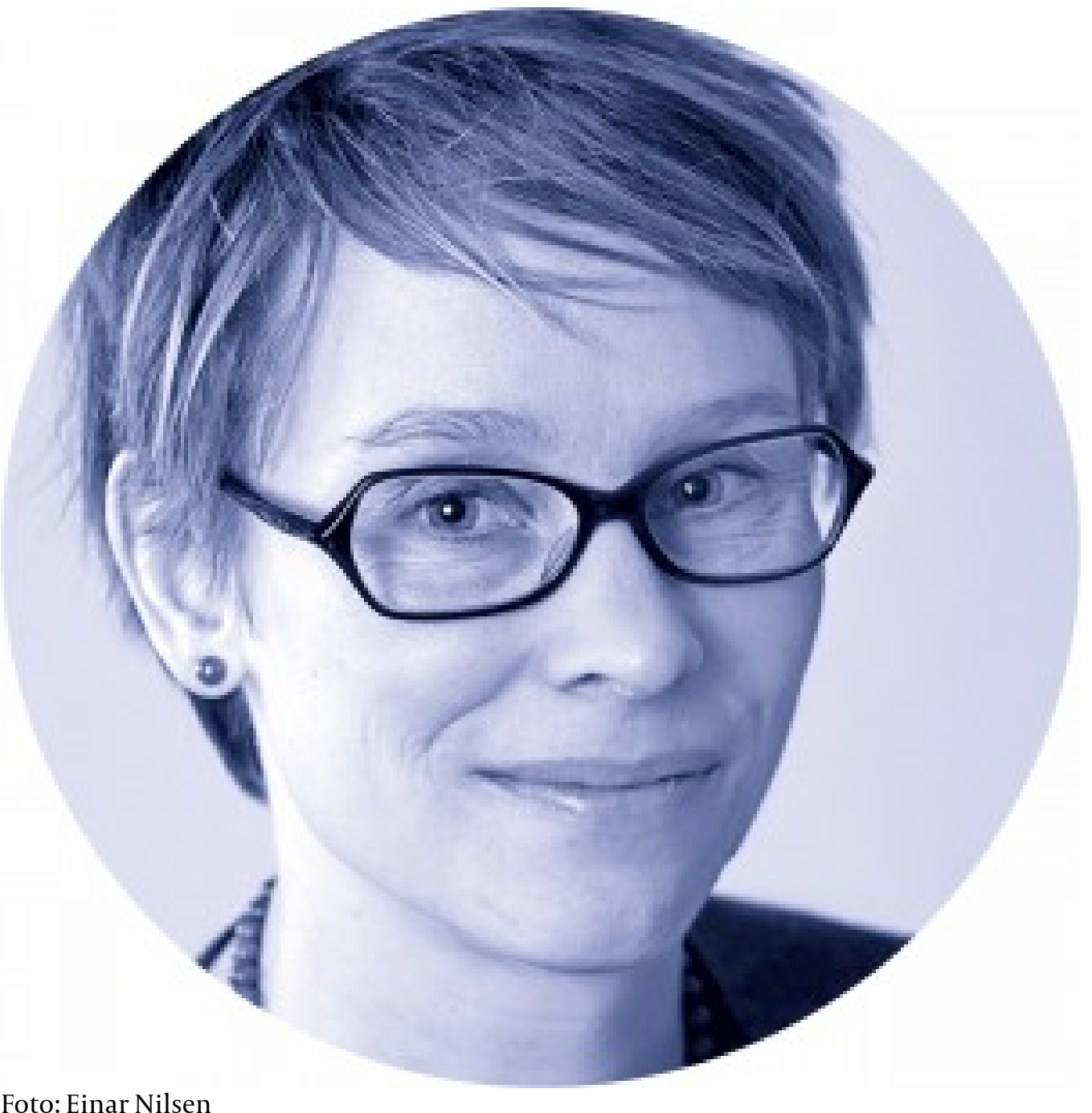


Norge befinner seg i en unntakstilstand. Skoler og barnehager er stengt. Alle som ikke av samfunnsmessige grunner er nødt til å gå på jobb, er bedt om å holde seg hjemme og ha minst mulig kontakt med hverandre. Sykehusene ruster opp. Flere ganger om dagen kommer nyheter om nye tiltak i ulike deler av landet, tiltak vi ikke har sett maken til i fredstid.

Alt vi gjør nå, gjør vi for å prøve å begrense spredningen av koronavirus. Eksperter over hele verden er enige. Det eneste som kan hindre covid-19-sykdommen å spre seg til de eldre og de spesielt utsatte, er kollektiv dugnad. For, som den danske avisen Berlingske skriver, denne krisen handler om samfunnets svakeste (1). Mens de ressurssterke har tatt smitten med hjem fra utlandet, og kanskje selv bare får lette symptomer, er det de syke og gamle som kan ende opp med å betale prisen.

I Norge har vi lang tradisjon for å stå sammen når det gjelder. Likhetstanken og ideen om solidaritet står sterkt. Det kan vi være stolte av. Nå er tiden kommet til å omsette våre idealer i praksis.

Helsepersonell i primærhelsetjenesten og på sykehus går en tøff tid i møte. Flere kommuner og sykehus frykter mangel på personell, og helsepersonell som jobber i andre yrker, har blitt bedt om å ta kontakt. Den overveldende responsen er gode nyheter og vitner om samholdet blant landets leger, sykepleiere og andre helsearbeidere. Også

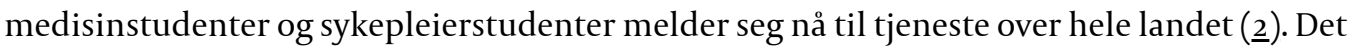
var neppe slik studentene hadde sett for seg slutten av studieåret. Disse må tas godt imot og, som lederne i Norsk medisinstudentforening minner oss på, gis nødvendig opplæring i bruk av smittevernutstyr (3).

\section{«Så hold ut, hold sammen»}

Flere medier har de siste dagene berettet om hvordan italienere i karantene holder moralen oppe ved å synge sammen (4.). Folk trekker ut på balkongene sine og fyller gatene med sang. Slik styrker de fellesskapet, selv om de ikke fysisk kan møtes. Den gode ideen har allerede spredd seg til mange land. Nå stiller også norske innbyggere seg på balkonger og tak for å klappe, synge og gi en velfortjent hyllest til helsepersonell som står på i denne vanskelige tiden (5).

I forrige uke ble Jahn Teigen gravlagt. Norge rakk så vidt å ta farvel med den folkekjære artisten dagen før myndighetene innførte forbud mot større forsamlinger. Selv om musikeren og sangeren, som kulturminister Abid Raja i sin tale kalte «en nasjonalskatt» nå er gått bort, lever minnet om ham videre. Og sangene hans gir oss fortsatt styrke. Blant de gripende innslagene under bisettelsen var fremføringen av Teigens vakre vise «Slå ring» av Alexander Rybak og Tønsberg domkirkes jentekor helt til slutt. "Så hold ut, hold sammen», sang koret. «Slå ring om hverandre, slå ring om din bror». Det skal vi gjøre.

\section{LITTERATUR}

1. Winther B. Billedet brænder seg fast: Den rige, raske og rejsende klasse smitter de svakeste. Berlingske 15.3.2020. https://www.berlingske.dk/danmark/billedet-braender-sig-fast-den-rige-raske-ogrejsende-klasse-smitter-de Lest 15.3.2020.

2. Storvik AG, Tømmerbakke SG. Ber medisinstudenter over hele landet om hjelp. Dagens Medisin 13.3.2020. https://www.dagensmedisin.no/artikler/2020/o3/13/ber-medisinstudenter-over-hele-landetom-hjelp/ Lest 15.3.2020.

3. Cappelen X, Ulsaker H. Arbeidsjern - med riktig opplæring i smittevernutstyr! Dagens Medisin 14.3.2020. https://www.dagensmedisin.no/artikler/2020/o3/14/arbeidsjern--med-riktig-opplaring-ismittevern/ Lest 15.3.2020.

4. NTB. Italienerne i koronakarantene synger fra balkongene. Dagsavisen 14.3.2020.

https://www.dagsavisen.no/nyheter/verden/italienerne-i-koronakarantene-synger-fra-balkongene- 
1.1681376 Lest 15.3.2020.

5. Nipen K, Hagesæther PV. Hyller helsevesenet fra balkongene sine. Aftenposten 15.3.2020.

https://www.aftenposten.no/norge/i/dO2oJz/hyllet-helsevesenet-fra-balkongene-sine Lest 15.3.2020.

Publisert: 17. mars 2020. Tidsskr Nor Legeforen. DOI: 10.4045/tidsskr.20.0219

(C) Tidsskrift for Den norske legeforening 2023. Lastet ned fra tidsskriftet.no 26. april 2023. 